\title{
An experimental tailor-made ESP course: experience of teaching English to students of Economics
}

\section{Shirokikh, Anna Yurievna}

Department of Foreign language Studies, Financial University under the Governemnet of the RF, Russia.

\begin{abstract}
The purpose of the study was to find out how enhanced learner autonomy techniques can influence students' professional communication skills, subject-specific knowledge, levels of motivation in studing the language and general satisfaction from the studies. The problem under investigation is if students should be allowed to choose the materials for language input and if the teacher will be able to work out an appropriate didactic approach in developing students' grammar accuracy, vocabulary range, speaking, listening and writing skills. The experimental course was designed for students of Economics. Students' responsibility, the use of online resouces and students' freedom in selection of teaching materials are viewed as key elements of the approach. The methodology of the course is worked out on the basis of close teacher-student interaction in and out of class. The results indicate that despite the fact that the course was time-consuming for both teachers and students, there are some positive results in respect of increased subject-specific knowledge and levels of motivation.
\end{abstract}

Keywords: learner autonomy, didactics, choice of language input, guided and unguided activities, motivation, professionalization in language studies. 


\section{Introduction}

The present study was undertaken in response to criticism received from students who expressed disappointment about the contents of the English language course. They did not want to study traditional textbooks, e.g. The Business by John Allison et al., as they are not subject-specific enough. In general, most students voted for the use of mass media and Internet sources and wanted to learn more terminology of their field of knowledge. Such complaints are not new for ESP teachers who often state that traditional English textbooks are outdated and not close to reality, making it difficult to arouse students' enthusiasm for learning (Lou, 2017, p.121).

The aim of this article is to describe a teaching approach to constructing tailor-made, subject-specific courses and to evaluate their didactic benefits. The basis of the approach is learner autonomy concept, traditionally understood as 'the ability to take charge of one's own learning' (Holec, 1981, p. 3).

\section{Literature Review}

Learner autonomy has been in focus of teachers' attention for thirty years now. There is much theoretical research devoted to a healthy and realistic learning environment (Munzur, 2012, p.80); the new role of teacher as a facilitator or counsellor (Sharle\&Szabo, 2000, p. 4); metacognitive knowledge with such dimensions as the learner, the learning task and the learning process (Crabbe et al., 2001, p.11); development of self-managerial skills and selflearning opportunities inside or outside the university (Sbaihi, 2015, p.102).

A facilitator of autonomous learning is the use of online technologies. Levy's study indicated that the use of online resources constitutes around $80 \%$ among students, which leads to new conceptions of teacher roles and materials development (Levy, 2014, p. 245). Immersion programs that add authenticity to the language studies can be created by the extensive use of ICT and multimedia (Muslem\&Abbas, 2017, P.204).

Balsikani (2010, p. 95) believes that students must have freedom of choice of materials that they employ in the classroom despite the fact that there are considerable limitations on the extent to which autonomy can be productively promoted with learners (Borg, 2012, p.21). Another study reports that students' interaction with literature resources and learning independence, potential measures of selfmanagement increase with exposure to Internetbased assignments (Henri et al., 2018, P.508). Increased use of Internet leads to introduction of the notions of inverted teaching scenarios and flipped classroom. The concept of inversion is seen as a method to let the students study on their own and then take time to discuss their questions in class (Pfennig, 2017, p.74); to enable the development of skills that are conducive to professional success (Siegeris, 2017, P.357); to provide 
interactive learning activities during lesson and individual teaching based on computer resources (Ayçiçek\& Yelken, 2018, 386). All that indicates a shift to a learner-centered approach in teaching (Steinberger, 2017, p. 322).

\section{Methodology}

The idea that students are to be allowed to choose materials for language input on their own is not new. Thus, Siegeris (2017) proposes a LearnTeamPlenum method where the first stage is to get students investigate a certain topic on their own instead of giving them a prepared script. The novelty of the method suggested in this paper is that we believe it possible to give students freedom in selecting textual input not just for a lesson or two, but for more extended periods of time, e.g. a semester, and students prepare activities for group discussions and exersices on grammar and lexis on their own. Thus, the role of the teacher is just to supervise the process and issue guidelines on how to organize the activities (wordings, language input, types of assignments etc.)

The underlying methodology for designing a tailor-made subject-specific English language course includes eight stages. A more detailed view of the methodological approach is presented in the table below (Table 1). The evaluation of the teacher's role is based on Harmer's (2001, p.110) taxonomy, i.e. the roles of a controller, prompter, participant, resource or tutor.

Table 1.

\begin{tabular}{|l|l|l|l|}
\hline & Activities & $\begin{array}{l}\text { Teacher's } \\
\text { role }\end{array}$ & Students' role \\
\hline $\begin{array}{l}\text { Step 1 (pre- } \\
\text { stage) }\end{array}$ & $\begin{array}{l}\text { After consulting colleagues, teaching } \\
\text { professional disciplines, teacher initializes a } \\
\text { Choosing a } \\
\text { theme and } \\
\text { correspondi a series of lessons and } \\
\text { ng language } \\
\text { input }\end{array}$ & $\begin{array}{l}\text { Tutor } \\
\text { where relevant information could be found. }\end{array}$ & $\begin{array}{l}\text { Passive } \\
\text { leaners } \\
\text { recipients of } \\
\text { information }\end{array}$ \\
\hline $\begin{array}{l}\text { Step 2 } \\
\text { Working out } \\
\text { a subject- } \\
\text { specific } \\
\text { problem for } \\
\text { discussion } \\
\text { and }\end{array}$ & $\begin{array}{l}\text { Students' home assignment is to look } \\
\text { through the sites and be prepared to } \\
\text { worth further investigation. Students are } \\
\text { allowed to reformulate the theme and to add } \\
\text { more Internet sites to the list of resources. } \\
\text { Teacher distributes the tasks for the next }\end{array}$ & $\begin{array}{l}\text { Tutor and } \\
\text { Prompter }\end{array}$ & $\begin{array}{l}\text { Active } \\
\text { learners: } \\
\text { Counsellors } \\
\text { and process } \\
\text { observers }\end{array}$ \\
\hline
\end{tabular}




\begin{tabular}{|c|c|c|c|}
\hline $\begin{array}{l}\text { distributing } \\
\text { tasks }\end{array}$ & $\begin{array}{l}\text { class, e.g. students may be asked to find an } \\
\text { audio or text file and prepare comprehension } \\
\text { questions on its contents, to make up a list of } \\
\text { terms key to understanding the theme, a } \\
\text { graph explaining a process etc. }\end{array}$ & & \\
\hline $\begin{array}{l}\text { Step } 3 \\
\text { Independent } \\
\text { home } \\
\text { assignments }\end{array}$ & $\begin{array}{l}\text { Students complete their home assignments } \\
\text { turning to teacher for help if necessary. They } \\
\text { choose textual / audio / graphic resources } \\
\text { and prepare comprehension and vocabulary } \\
\text { assignments for in-class activities. Teacher } \\
\text { provides extensive guidelines. } \\
\text { Students share text / audio / graphic files } \\
\text { with the rest of the group in online format - } \\
\text { on Yandex disk. The other students read, } \\
\text { listen, analyse the contents before the actual } \\
\text { class. }\end{array}$ & Resourse & $\begin{array}{l}\text { Active } \\
\text { learners: } \\
\text { Personal } \\
\text { activities and } \\
\text { peer support } \\
\text { (if asked to } \\
\text { work as } \\
\text { group) } \\
\text { Individual / } \\
\text { group out-of- } \\
\text { class work }\end{array}$ \\
\hline $\begin{array}{l}\text { Step } 4 \\
\text { Controlled } \\
\text { practice }\end{array}$ & $\begin{array}{l}\text { The lesson starts with controlled practice, } \\
\text { i.e. a variety of comprehension and } \\
\text { vocabulary assignmets. Students come to } \\
\text { class with prepared controlled practice } \\
\text { activities based on textual (audio and visual) } \\
\text { and graphic input: gap-filling, matching, } \\
\text { dictations, quizzes, questionnaires, true/false } \\
\text { questions, labelling a graph, chart or picture } \\
\text { etc. It is possible that students prepare } \\
\text { activities in digital format, e.g. on the } \\
\text { platform "Quizzlet". Teacher is to note any } \\
\text { deficiencies in students' performance, but } \\
\text { does not give any feedback. } \\
\text { The home assignment for the next class is to } \\
\text { compile a glossary of thematic vocabulary. } \\
\text { This glossary is kept as a Google table file } \\
\text { accessible by all the students within the } \\
\text { group and it represents a source of freer } \\
\text { practice assignments worked out under the } \\
\text { teacher's supervison. The teacher's role is } \\
\text { also to suggest some theoretical aspects of } \\
\text { lexis used, e.g. insights into semantics, } \\
\text { etymology, degree of metaphorization, }\end{array}$ & Participant & $\begin{array}{l}\text { Active } \\
\text { learners: } \\
\text { Case } \\
\text { presenters } \\
\text { Moderators } \\
\text { Counsellors } \\
\text { Process } \\
\text { observers } \\
\text { In-class / out- } \\
\text { of-class group } \\
\text { work }\end{array}$ \\
\hline
\end{tabular}




\begin{tabular}{|c|c|c|c|}
\hline & $\begin{array}{l}\text { contextual use of terms and peculiarities of } \\
\text { translation. Teacher also issues instructions } \\
\text { on the use of dictionaries and expands on } \\
\text { properties of terms in respect of their } \\
\text { concept-making functions. }\end{array}$ & & \\
\hline $\begin{array}{l}\text { Step } 5 \\
\text { Freer } \\
\text { practice }\end{array}$ & $\begin{array}{l}\text { The stage of freer practice is based on the } \\
\text { glossary compiled by students as their home } \\
\text { assignment. Activities can be quite different } \\
\text { from "storytelling" (expand on the history of } \\
\text { a term) to making up mind maps of the } \\
\text { terms given, solving cases, comparing } \\
\text { notions, listing, ranking, ordering, } \\
\text { sequencing, classifying, describing pictures, } \\
\text { maps or graphs. The role of the teacher here } \\
\text { is just to explain what tasks may be } \\
\text { applicable in the classroom context and } \\
\text { check if the language is correct and } \\
\text { appropriate to the theme. }\end{array}$ & Participant & $\begin{array}{l}\text { Active } \\
\text { learners: } \\
\text { Case } \\
\text { presenters } \\
\text { Moderators } \\
\text { Counsellors } \\
\text { Process } \\
\text { observers } \\
\text { In-class group } \\
\text { work }\end{array}$ \\
\hline $\begin{array}{l}\text { Step } 6 \\
\text { Teacher's } \\
\text { feedback }\end{array}$ & $\begin{array}{l}\text { Throuout the previous in-class activities } \\
\text { teacher is to take notes about students' } \\
\text { verbal behaviour, i.e. the range of grammar } \\
\text { structures and collocations, the style of } \\
\text { message delivary, the depth of topic } \\
\text { investigation etc. At this stage teacher is to } \\
\text { offer studnets grammar and vocabulary } \\
\text { exercises, suggest further oral assignments } \\
\text { in the form of guided practice. }\end{array}$ & Controller & $\begin{array}{l}\text { Passive } \\
\text { learners: } \\
\text { Receipients of } \\
\text { information, } \\
\text { guided } \\
\text { practice } \\
\text { In-class group } \\
\text { work }\end{array}$ \\
\hline $\begin{array}{l}\text { Step } 7 \\
\text { Students' } \\
\text { feedback }\end{array}$ & $\begin{array}{l}\text { Students are usually asked to give some } \\
\text { written or oral feedback on their own } \\
\text { performance in content and method at the } \\
\text { end of a series of lesson - to state which } \\
\text { assignments they liked or disliked, found } \\
\text { hard or easy, what information was missing } \\
\text { and what roles they would like to perform in } \\
\text { the next series of lessons. This feedback can } \\
\text { take the form of a survey as well. }\end{array}$ & Tutor & $\begin{array}{l}\text { Active } \\
\text { learners: } \\
\text { Self and peer } \\
\text { evaluation } \\
\text { In-class group } \\
\text { work }\end{array}$ \\
\hline $\begin{array}{l}\text { Step } 8 \\
\text { Preparing } \\
\text { the product }\end{array}$ & $\begin{array}{l}\text { The materials of all the assignments students } \\
\text { do throughout the series of lessons (audio } \\
\text { and text files, exercises, graphs, charts, PP }\end{array}$ & Tutor & $\begin{array}{l}\text { Active } \\
\text { learners } \\
\text { Self and peer }\end{array}$ \\
\hline
\end{tabular}




\begin{tabular}{|l|l|l|l|}
\hline $\begin{array}{l}\text { of the series } \\
\text { of lessons }\end{array}$ & $\begin{array}{l}\text { presentations, glossary) are collected on } \\
\text { Yandex disk, to which students and teacher } \\
\text { have shared access. These materials are used } \\
\text { further for revision before their end-of-the } \\
\text { course test. }\end{array}$ & $\begin{array}{l}\text { evaluation } \\
\text { Out-of-class } \\
\text { group work }\end{array}$ \\
\hline
\end{tabular}

The cycle can be repeated several times througout the course. Thus, students, who specialize in Business for the Energy Industry, studied ten themes during the school year, such as Sources of Energy, Industrial / Individual Energy consumption, Energy policies worldwide, Environmental protection and Eco-design, Marketing in the Energy Sector, Financila viability of Investment, Research and Product Development, The use of Blockchain technologies, Internet of Things for the Energy Industry. The framework of the syllabus was presented by the stages described above.

\section{Results}

The goal of this article is not only to present a didactic approach to constructing a tailormade, subject-specific, "on-spot" course, but also to evaluate how helpful this approach may be in enhancing students' hard and soft skills. At the end of the year, we carried out a survey in which 45 student respondents (three groups) were to assess the results of their studies by choosing "yes", "no" and "I doubt" options in answer to the questions listed below. The first two questions refer to the development of hard skills, i.e. language skills and knowledge of their subject-specific domain, while questions 3-5 are about soft skills acquisition, i.e. more universal competencies, such as autonomy, time management and motivation:

1. Has the course helped you to develop professionally?

2. Has the course helped you to develop language fluency?

3. Can you say that you are more independent in your language studies now?

4. Is the course more difficult and time-consuming than your previous language studies?

5. Are you more motivated to learn the language now than before? 


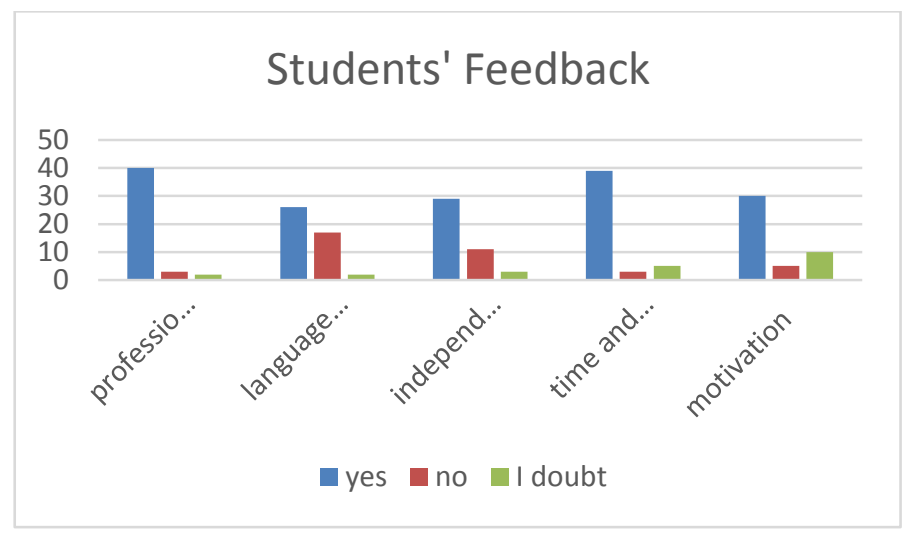

Figure 1.

The vertical axis in the bar chart represents the number of students and as the results show forty out of forty five students highly evaluated the impact of the course on their professional development. It means that the course allowed to expose students to more subject-specific language.

On the other hand, students did not quite achieve the expected level of language fluency (sisteen students said "no" in answer to the question if their knowledge of the language is enhanced). That may be explained by the fact that traditional textbooks are much more didactically viable than a course made "on spot".

The independence aspect also was a bit disappointing, i.e. eleven students did not notice any positive trend in their learner's autonomy. The reason is that students may find autonomous activities rather challenging as they have never been exposed to unguided assignments before. They have got used to rely on the teacher in his role of a supervisor.

Time and effort aspect resulted in increased preparation time. Thirty nine students from the target group complained that it took them too much time to prepare the assignments, to be in touch with their teacher and peer students on the regular basis. But in subsequent interviews they also stated that there was some sense of achievement in what they were doing.

Thirty students indicated that the course had had a profound impact on their motivation. In fact, most of them claimed that now they are able to learn the language on their own, as they have acquired the necessary skills for autonomous learning.

\section{Conclusions}

The rationale for the course was based on the assumption that learner autonomy and the use of internet sources instead of traditional textbooks may increase students' professional 
development, motivation in learning a language and general language skills. The change in contents and didactics in teaching ESP is undergoing major transformations with the increased use of digital technologies, learners' requirements of immediate results and the lag in time between publishing an ESP textbook and new trends in subject-specific areas. Thus, the content component of the course was provided by search for viable subjectspesific topics, textual (audio and visual) verbal input and students' autonomous preparation of assignments for in-class and out-of-class activities. The teacher's role changed from class to class depending on the stage of the syllabus, i.e. from the role of a tutor to the role of a resource, a participant, a prompter or a controller.

The survey conducted at the end of the course suggests that more autonomy leads to enhanced motivation and professional development, but further research is needed in order to understand how tailor-made, "on spot" courses may compete with traditional textbook in respect of developing language fluency and communication skills. More experiments are needed to define the applicability of such courses for students of lower levels of language proficiency, different individual styles and different age groups.

\section{References}

Ayçiçek, B., Yelken T.Y. (2018) The Effect of Flipped Classroom Model on Students' Classroom Engagement in Teaching English. International Journal of Instruction, 11, No.2, 385-398.

Bal31kanl1, C. (2010). Learner Autonomy In Language Learning: Student Teachers' Beliefs. Australian Journal of Teacher Education, 35 (1), 90-103.

Borg, S. (2012) Learner Autonomy: English Language Teachers'Beliefs and Practices. London, British Council.

Crabbe, D., Hoffmann, A., Cotterall, S. (2001). Examining the Discourse of Learner Advisory Sessions in Learner Autonomy: New Insights. In L. Dam (ed.). The AILA Review 15. Huddersfield, West Yorkshire: The Charlesworth Group.

Harmer J. (2001). The Practice of English Language Teaching. 3rd edition. Longman.

Henri D. C., Morrell L. J., Scott G. W. (2018) Student perceptions of their autonomy at University. High Education, 75, 507-516.

Holec, H. (1981). Autonomy in Foreign Language Learning. Oxford: Pergamon.

Lou, M. (2017) Design of English Multimedia Teaching System Based on Diversification Theory. International Journal of Emerging Technologies in Learning, 12 (1), 119-129.

Munzur, Z. (2012). Promoting Learner Autonomy through Portfolio. Journal of Education and Future, 2, $75-92$.

Muslem A., Abbas M. (2017) The Effectiveness of Immersive Multimedia Learning with Peer Support on English Speaking and Reading Aloud. International Journal of Instruction, 10 (1), 203-218. 
Pfennig, A. Flipping the Classroom and Turning the Grades - a Solution to Teach Unbeloved Phase Diagrams to Engineering Students. Proceedings of the 3rd International Conference on Higher Education Advances, HEAd'17. Universitat Polit`ecnica de Val`encia, Val`encia, 73-81.

Sbaihi, M. (2015). Learner Autonomy for Learner Development (Reflections on the Moroccan University EFL Context). International Journal of Technical Research and Applications, 30, 101-104.

Scharle, A., Szabo, A. (2000). Learner Autonomy. A Guide to Developing Learner Responsibility. Cambridge University Press.

Steinberger, C. (2017) In Search of Reusable Educational Resources in the Web. Proceedings of the 3rd International Conference on Higher Education Advances, HEAd'17. Universitat Polit'ecnica de Val`encia, Val'encia, 321-328. 